ACTA MYCOLOGICA

Vol. 45 (1): 45-56

2010
Dedicated to Professor Barbara Gumińska on the occasion of her eighty-fifth birthday

\title{
Polish resupinate Russulales: the genus Vararia
}

\author{
DARIUSZ KARASIŃSKI \\ Department of Mycology, W. Szafer Institute of Botany, Polish Academy of Sciences \\ Lubicz 46, PL-31-512 Kraków, d.karasinski@botany.pl
}

Karasiński D.: Polish resupinate Russulales: the genus Vararia. Acta Mycol. 45 (1): 45-56, 2010.

The paper discusses three corticioid species of the genus Vararia P. Karst. Two species, Vararia gallica (Bourdot \& Galzin) Boidin and Vararia ochroleuca (Bourdot \& Galzin) Donk, are reported from Poland for the first time. The cosmopolitan species Vararia investiens $\mathrm{P}$. Karst., previously known only from one Polish record, was rediscovered after over 100 years since the previous Polish collection. Macro- and micromorphological characters of the Polish collections are described and illustrated. The knowledge of their distribution and ecology is briefly summarized. A key to European members of the genus is given.

Key words: Vararia, Peniophoraceae, resupinate Russulales, fungal diversity

\section{INTRODUCTION}

The genus Vararia P. Karst. belongs to a large family Peniophoraceae Lotsy in the order Russulales Kreisel ex M.P. Kirk, P.F. Cannon \& J.C. David (Miller et al. 2006; Larsson 2007). It was first described by Karsten (1889) as a subgenus of Xerocarpus $P$. Karst. for Xerocarpus alutarius (Berk. \& M. A. Curtis) P. Karst., which was later found to be a synonym of Radulum investiens Schwein. Karsten (1898) raised Xerocarpus subgen. Vararia to the generic rank. Type of the genus is a species with a dimitic hyphal system, clamped generative hyphae, dextrinoid dichohyphidia, sulphopositive gloeocystidia, utriform basidia, and smooth, thin-walled, fusoid basidiospores with an amyloid suprahilar plage. The second species, Vararia ochroleuca (Bourdot \& Galzin) Donk, originally described under the name Asterostromella ochroleuca Bourdot \& Galzin, was transferred to the genus by Donk (1930), and several further species were moved to Vararia by Rogers and Jackson (1943). The genus was later studied by Cunningham (1955, 1963), Gilbertson (1965) and Welden (1965), who described some new species from New Zealand, North and Central America, respectively. Vararia was studied in detail by Boidin, Lanquetin and Gilles. They described many new species from French overseas territories (Guadeloupe, Réunion), 
Gabon and the Central African Republic (e.g., Boidin 1967; Boidin, Lanquetin 1975, 1977, 1984; Boidin et al. 1976, 1987; Boidin, Gilles 1999). The genus was also studied in Asiatic Russia (Parmasto 1965, 1970), Argentina (Greslebin, Rajchenberg 1997) and Hawaii (Gilbertson, Hemmes 1997). It is quite well known at present and includes about 60 species which mainly occur in tropical and subtropical areas of the world (Boidin, Gilles 1999; Hjortstam, Ryvarden 2007). In Europe Vararia is not well represented, having only 7 species, all of which are rarely reported (Hallenberg, Eriksson 1985; Boidin, Michel 1998).

In Poland, only Vararia investiens was previously reported from three localities situated closely together in the vicinity of Międzyrzec Podlaski (NE Poland) (Eichler 1900, 1904, as Corticium investiens (Schwein.) Bres.). Vararia species were not reported from Poland over the next one hundred years.

The aim of this paper is to review the current state of knowledge on the genus Vararia in Poland.

\section{MATERIAL AND METHODS}

The study is based on specimens collected by the author during field studies in the Białowieża Forest (Równina Bielska plain), the Kaszubski Landscape Park (Pojezierze Kaszubskie lakeland) and the Puszcza Niepołomicka forest (Nizina Nadwiślańska lowland), carried out during the vegetation seasons of 2008 and 2009.

The colour and configuration of the hymenial surface and marginal zone were noted using fresh specimens. Macromorphological characters were additionally observed in dried materials, while micromorphological characters only in dried specimens. Freehand sections of each specimen were made under a Nikon SMZ-2T microscope with a normal razor blade and observed under a Nikon Eclipse E-400 light microscope with $\times 1250$ magnification and using an oil immersion objective. Microstructural elements were examined and measured in Melzer's reagent, 5\% $\mathrm{KOH}$ and cotton blue in lactic acid. Sulphovanillin was used to observe reactions of gloeocystidia. The formulae for these can be found in Hjortstam et al. (1987). Spore measurements in the descriptions of the species are based on 30 measurements per specimen. The following abbreviations are used in the descriptions of species: $\mathrm{L}^{\mathrm{m}}=$ mean length of all measurements of spores from all collections of the species, $\mathrm{W}^{\mathrm{m}}=$ mean width of all measurements of spores from all collections of the species, $\mathrm{Q}^{\mathrm{m}}=\mathrm{L}^{\mathrm{m}}$ to $\mathrm{W}^{\mathrm{m}}$ ratio, $\mathrm{Q}=$ length to width range ratio, $\mathrm{n}=$ number of measurements. Spore size is given without the apiculus. Extreme values are given in parentheses and the $90 \%$ most commonly recorded values are given in between. None of the measurements were taken from a spore print. Line drawings were made by author with a drawing tube (Nikon Y-IDT) or were made from images acquired with a Nikon Coolpix 4500 digital camera. Specimens are deposited at KRAM and duplicates are in the author's private herbarium (DK). 


\section{RESULTS AND DISCUSSION}

Vararia gallica (Bourdot \& Galzin) Boidin

Figs 1-3

Bull. Soc. Nat. Oyonnax 5: 78 (1951).

Asterostromella epiphylla var. gallica Bourdot \& Galzin, Bull. Soc. mycol. Fr. 27(2): 265 (1911).

Asterostromella gallica (Bourdot \& Galzin) Bourdot \& Galzin in Pilát, Annls mycol. 25(3/4): 255 (1927).

Basidiocarps annual, resupinate, widely effused, membranaceous, waxy-crustose and partly pulverulent, very thin, up to $45 \mu \mathrm{m}$ thick, closely adnate, not separable. Margin not differentiated, thin but clear, rhizomorphs or hyphal strands absent. Hymenial surface smooth, indistinctly farinose, under the lens rough by projections of ultimate branches of dichohyphidia, whitish when fresh, whitish-grey to pale cream when dry. Hyphal system dimitic. Generative hyphae 1.5-3.0 $\mu \mathrm{m}$, without clamp connections, hyaline, thin-walled, forming very thin subicular layer consisting of hyphae parallel to the substratum. Catahymenium composed with dichohyphidia, gloeocystidia and basidia. Dichohyphidia grow singly or in small groups, rarely forming dense concentrations, dichotomously branched with branched part more or less globose in outline, resembling asterohyphidia of Asterostroma laxum Bres., with relatively long ultimate branches, up to $5 \mu \mathrm{m}$; individual branches thick-walled with narrow lumen, 1.5-2.0 $\mu \mathrm{m}$ wide, with subulate ends, thick walls strongly dextrinoid and cyanophilous, hyaline or pale cream-yellowish when observed in 5\% KOH. Gloeocystida 15.0-32.0 $\times$ 4.0-5.5 $\mu \mathrm{m}$, sulphonegative, cylindrical, clavate and fusiform, most often with a single or uniquely with two outgrowths up to $8 \mu \mathrm{m}$ long. Basidia cylindrical with constriction in the middle part to typically utriform, 23-42 $\times 4-6 \mu \mathrm{m}$, basal part up to $10.5 \mu \mathrm{m}$ wide, with 4 sterigmata, without basal clamp. Basidiospores (7.8-)9.6-11.2(-11.5) × (4.0-)4.4-5.0(-5.5) $\mu \mathrm{m}\left(\mathrm{L}^{\mathrm{m}}=9.89 \mu \mathrm{m} ; \mathrm{W}^{\mathrm{m}}=4.90 \mu \mathrm{m} ; \mathrm{Q}^{\mathrm{m}}=\right.$ 2.02; $\mathrm{Q}=1.7-2.52 ; \mathrm{n}=60)$, pin-shaped, lacrymoid to fusiform, always with rounded apex, smooth, hyaline, thin-walled, with indistinctly amyloid suprahilar plage, a few with oil droplets inside, non-dextrinoid, non-cyanophilous.

SPECIMENS EXAmined. Poland. Pojezierza Południowobałtyckie lakelands, Pojezierze Kaszubskie lakeland, Zawory, ca. $5 \mathrm{~km} \mathrm{SW}$ of Kartuzy, on the bank of the Jezioro Kłodno lake, Phragmitetum australis, on dead stems of Phragmites australis Trin. ex Steud., 25 Oct. 2008, leg. D. Karasiński 2548 (KRAM F-48006); the same locality, habitat and host, 30 Nov. 2008, leg. D. Karasiński 2569 (DK-2569).

Comments. Vararia gallica is distinguished from other European Vararia species by a whitish and very thin basidiocarp, the shape and size of spores, stellate dichohyphidia, the absence of clamps on generative hyphae and the occurrence in wet localities on dead stems of herbaceous plants or, rarely, on fallen twigs of deciduous trees (e.g., Salix). Vararia cremeoavellanea Pouzar is very similar but differs from Vararia gallica by having shorter spores (up to $9.5 \mu \mathrm{m}$ ) and wider gleocystidia (6-9 $\mu \mathrm{m})$. It occurs on dead wood in dry places with xerothermic vegetation.

Boidin \& Lanquetin (1975) selected Bourdot's collection from Juncus L. as the lectotype of Vararia gallica. V. gallica has also been reported from Anthriscus Pers., Dryopteris Adans., Rubus idaeus L., Rubus fruticosus L, Scirpus L., Typha L., Polygonatum Mill. and Salix. Dead stems of Phragmites australis, lying on the bank 


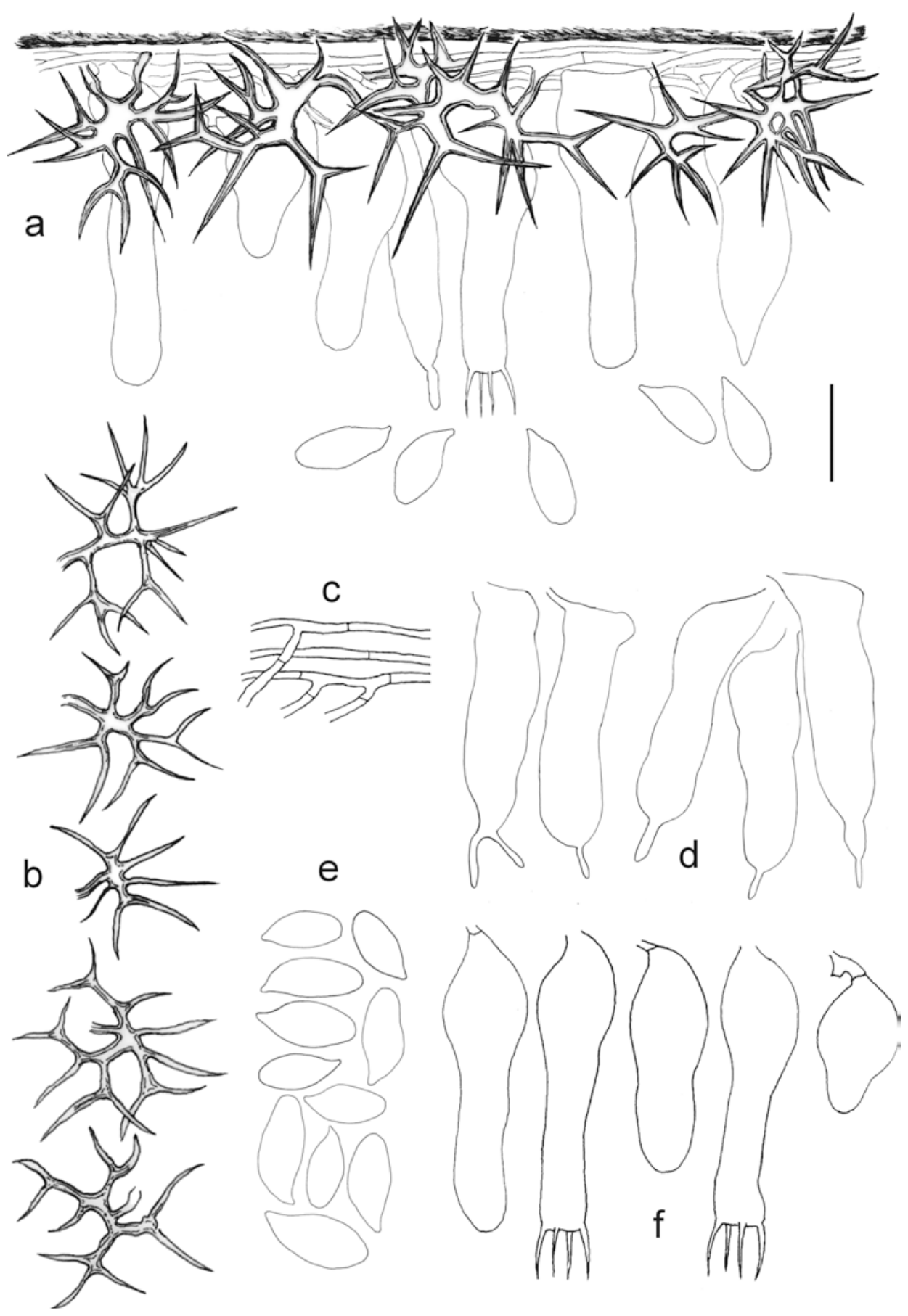

Fig. 1. Vararia gallica: a) fragment of section through basidocarp, b) dichohyphidia, c) generative hyphae, d) gloeocystidia, e) spores, f) basidioles and basidia KRAM F-48006. Scale bar $=10 \mu \mathrm{m}$. 


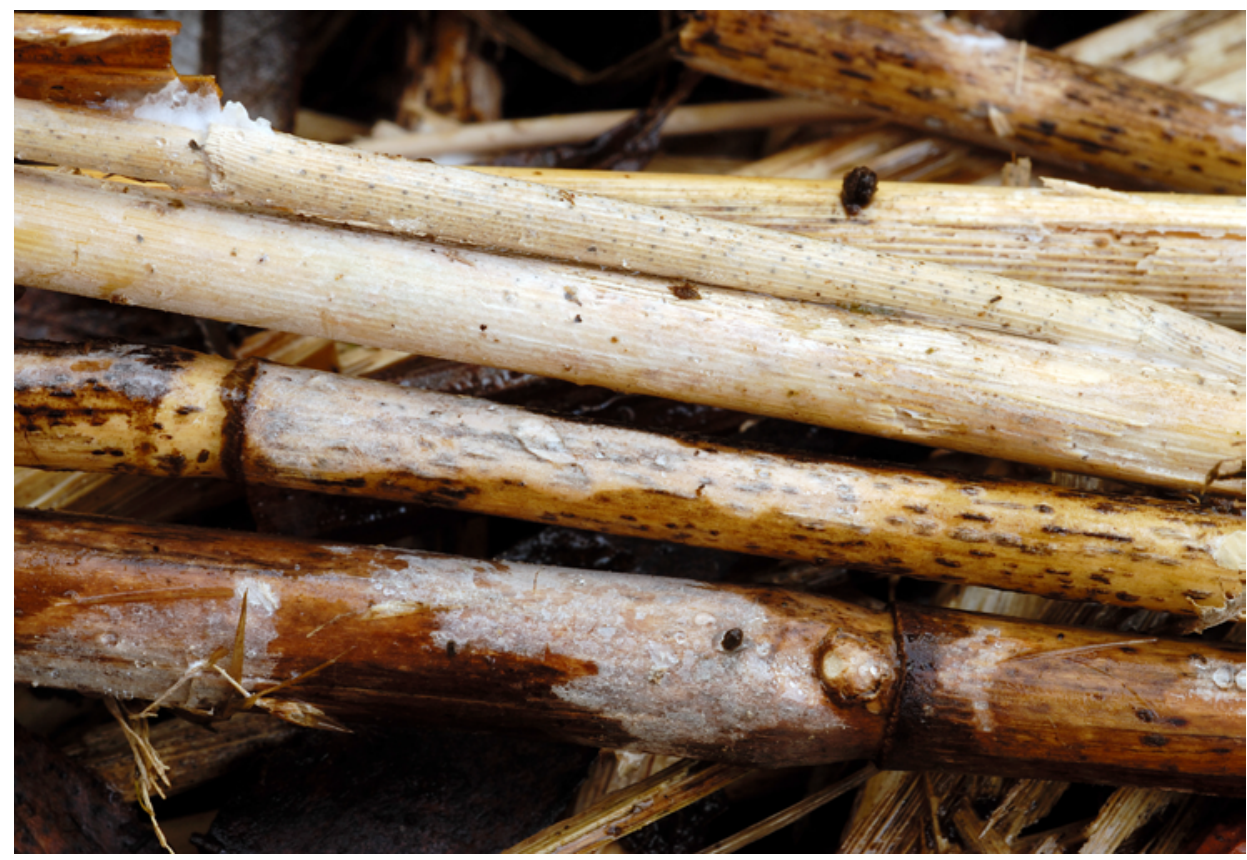

Fig. 2. Vararia gallica on dead stems of Phragmites australis KRAM F-48006 (Phot. D. Karasiński).

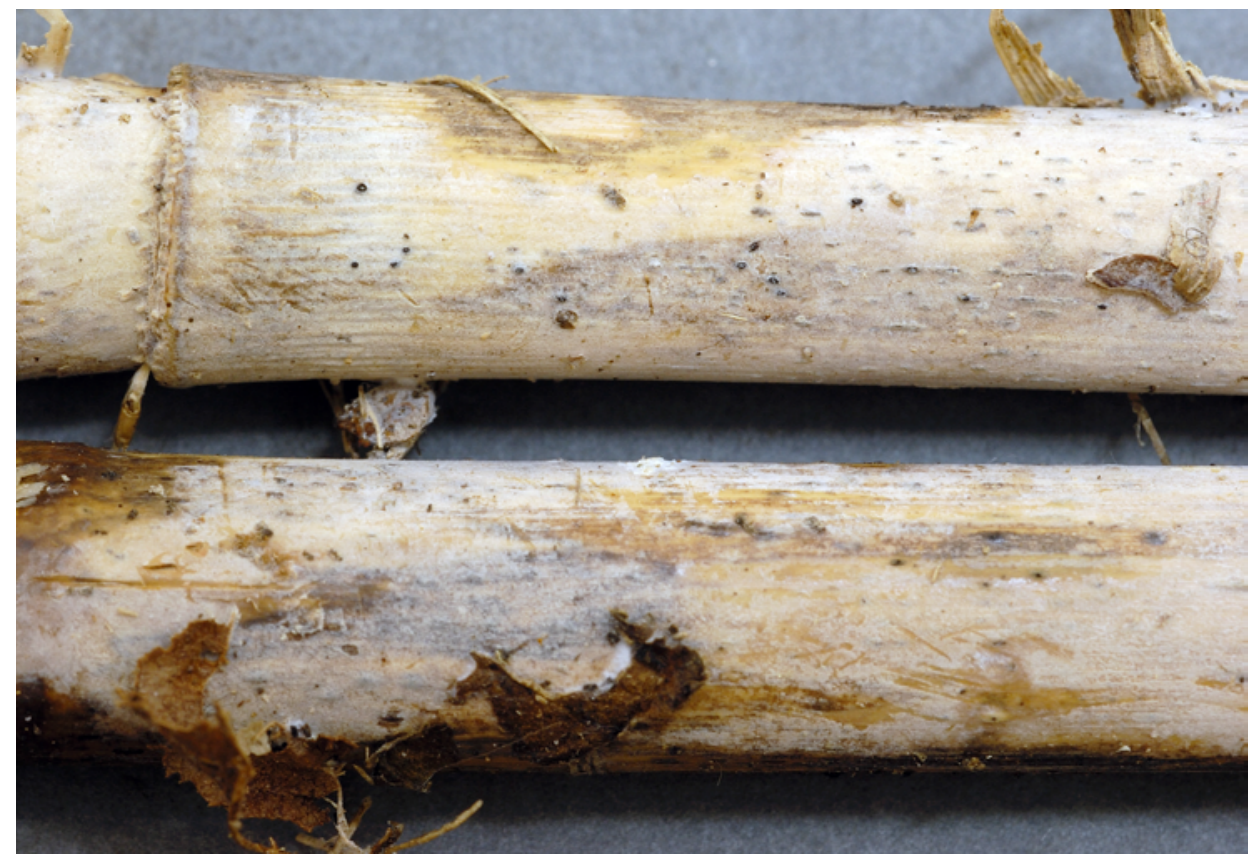

Fig. 3. Vararia gallica on dead stems of Phragmites australis DK-2569 (Phot. D. Karasiński). 


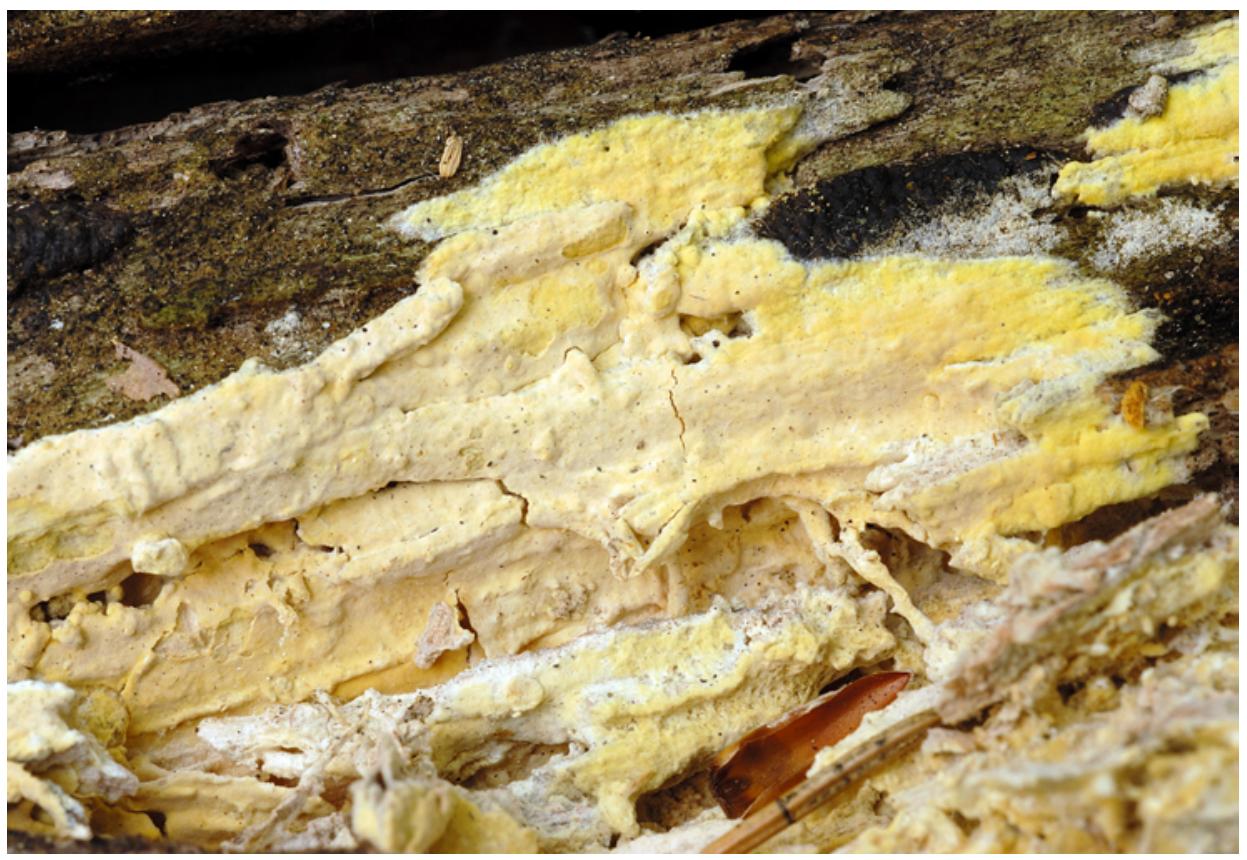

Fig. 4. Vararia investiens on rotten wood of fallen branch of Fagus sylvatica KRAM F-48008 (Phot. D. Karasiński).

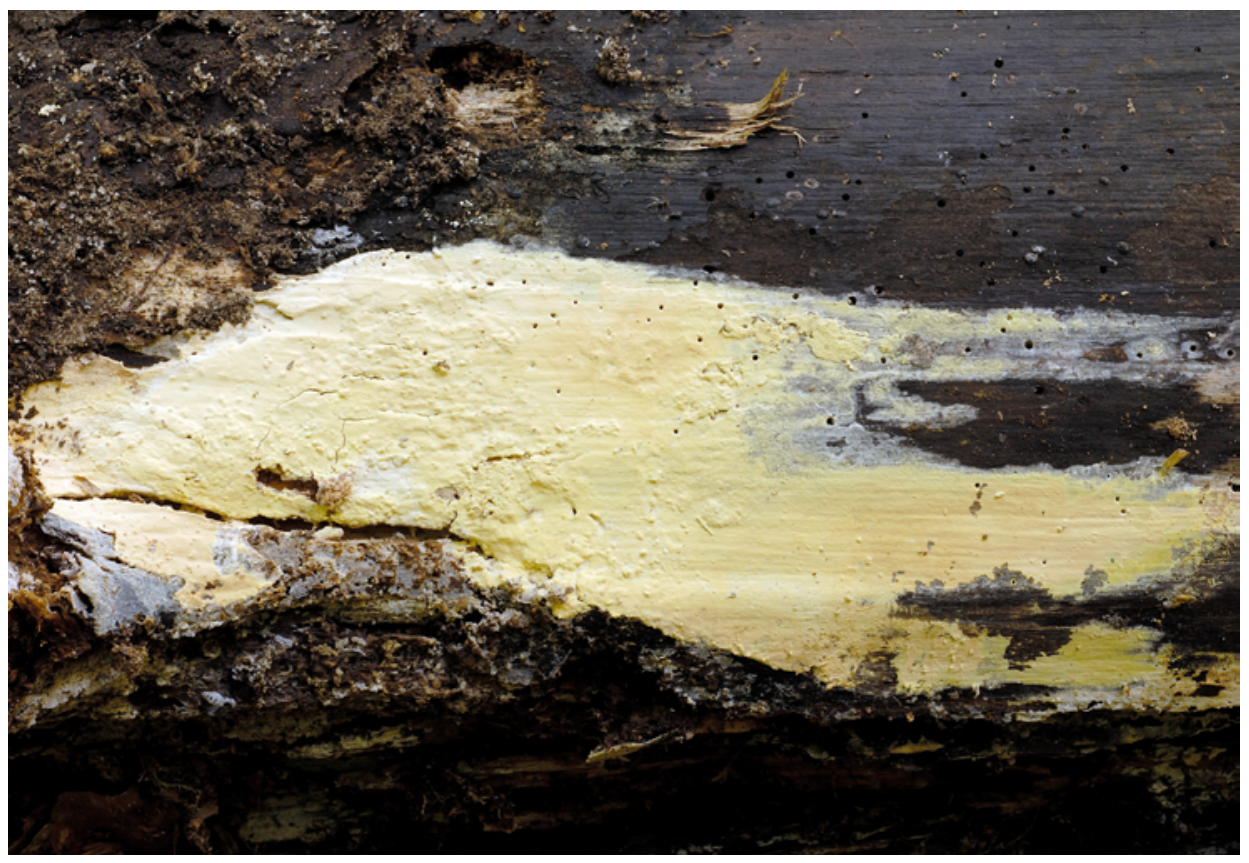

Fig. 5. Vararia investiens on rotten wood of fallen trunk of Populus tremula KRAM F-48009 (Phot. D. Karasiński). 
of the lake, are for the first time reported as a substrate for this species. In Poland, Phragmitetum australis (Gams 1927) Schmale 1939 is a commonly occurring plant association (Matuszkiewicz 2007), but its fungal diversity is poorly recognized (Mazurkiewicz-Zapałowicz et al. 2006). It may therefore be possible to find further localities of Vararia gallica in this plant association.

The literature data indicate that Vararia gallica is a very rare European species, reported from Denmark (Christiansen 1960), France (Boidin, Lanquetin 1975; Boidin, Gilles 1999; Boidin, Michel 1998), Germany (Grosse-Brauckmann, Kummer 2004), the Netherlands (Arnolds et al. 1995), the Czech Republic (Pouzar 1982), Sweden (Hjortstam 1984), Estonia (Parmasto, Parmasto 2005), Spain (Tellería 1990) and Poland. A single specimen of Vararia gallica was reported from the Lanaittu Valley in Sardinia in Italy. The specimen was collected from the stems of Helichrysum Mill. growing below the soil line (Bernicchia 2001; Onofri 2005). The occurrence on herbaceous plants is indeed characteristic of Vararia gallica, but the collection site has a hot and dry climate with thermo-xerophyte Mediterranean vegetation.

Vararia investiens (Schwein.) P. Karst.

Figs 4-6

Kritisk Öfversigt af Finlands Basidsvampar. Tillägg 3: 32. Helsingfors (1898).

Radulum investiens Schwein., Trans. Amer. Phil. Soc. II p. 165 (1832).

Corticium investiens (Schwein.) Bres., I. R. Accad. Agiati Atti III p. 110 (1897).

Corticium alutarium Berk. \& Cook, Grevillea 2(13): 4 (1873).

Basidiocarps annual, resupinate, widely effused, membranaceous when fresh to chalky-crustaceous when dry, not separable, up to $0.4 \mathrm{~mm}$ thick, forming irregular patches and linear areas up to $35 \mathrm{~cm}$ long and $10 \mathrm{~cm}$ wide. Hymenial surface smooth, slightly pulverulent under lens, cream, straw-coloured, warm yellow or ochraceous, sterile parts sometimes with a pale orange tint. Margin usually paler than the hymenial surface, thinning out, adnate, powdery to fibrillose, a few narrow hyphal strands sometimes present. Hyphal system dimitic. Generative hyphae clamped, clamps present at all primary septa, hyaline, 1.6-4.8 $\mu \mathrm{m}$ wide, scantly branched, mainly thinwalled, but thick-walled to nearly solid hyphae also present in the subicular layer and in the core of hyphal strands. Dichohyphae and dichohyphidia are predominant structures in all parts of the basidiocarp, thick-walled, with main branches 0.8-3.2 $\mu \mathrm{m}$ wide, pale yellow in $5 \% \mathrm{KOH}$, with variable dextrinoid reaction, from golden yellow red to dark red brown. Dichohyphae present in hyphal strands, subicular and subhymenial layer, with long main and ultimate branches, up to $55 \mu \mathrm{m}$, main branches up to $3 \mu \mathrm{m}$ wide. Dichohyphidia in the hymenial layer more robust than subicular and subhymenial ones, more or less ellipsoid in outline, with main branches up to $4.5 \mu \mathrm{m}$ wide, ultimate branches slender and pointed. Septate "elbow-like" swellings sometimes observed on the main branches of dichohyphidia. Catahymenium consists of dichohyphidia, basidia and gloeocystidia. Gloeocystidia irregular in shape, cylindrical, clavate to subulate, few with schizopapillae; subulate gloeocystidia $30-48 \times$ 3.5-4.8 $\mu \mathrm{m}$, cylindrical and clavate gloeocystidia 35-80 $\times 4-10 \mu \mathrm{m}$, thin-walled, with yellowish, granular content; all cystidia sulphonegative. Basidia scanty, cylindrical to clavate and elongate, with constriction, 30-45 $\times 4-5 \mu \mathrm{m}$, with 4 sterigmata, basal part up to $7.5 \mu \mathrm{m}$ wide. Basidiospores pip-shaped, lacrymoid to fusiform or clavatefusiform, with a rounded apex and long acuminate tip often separated from the main spore body by a (pseudo)septum, sometimes collapsed, smooth, thin-walled, 


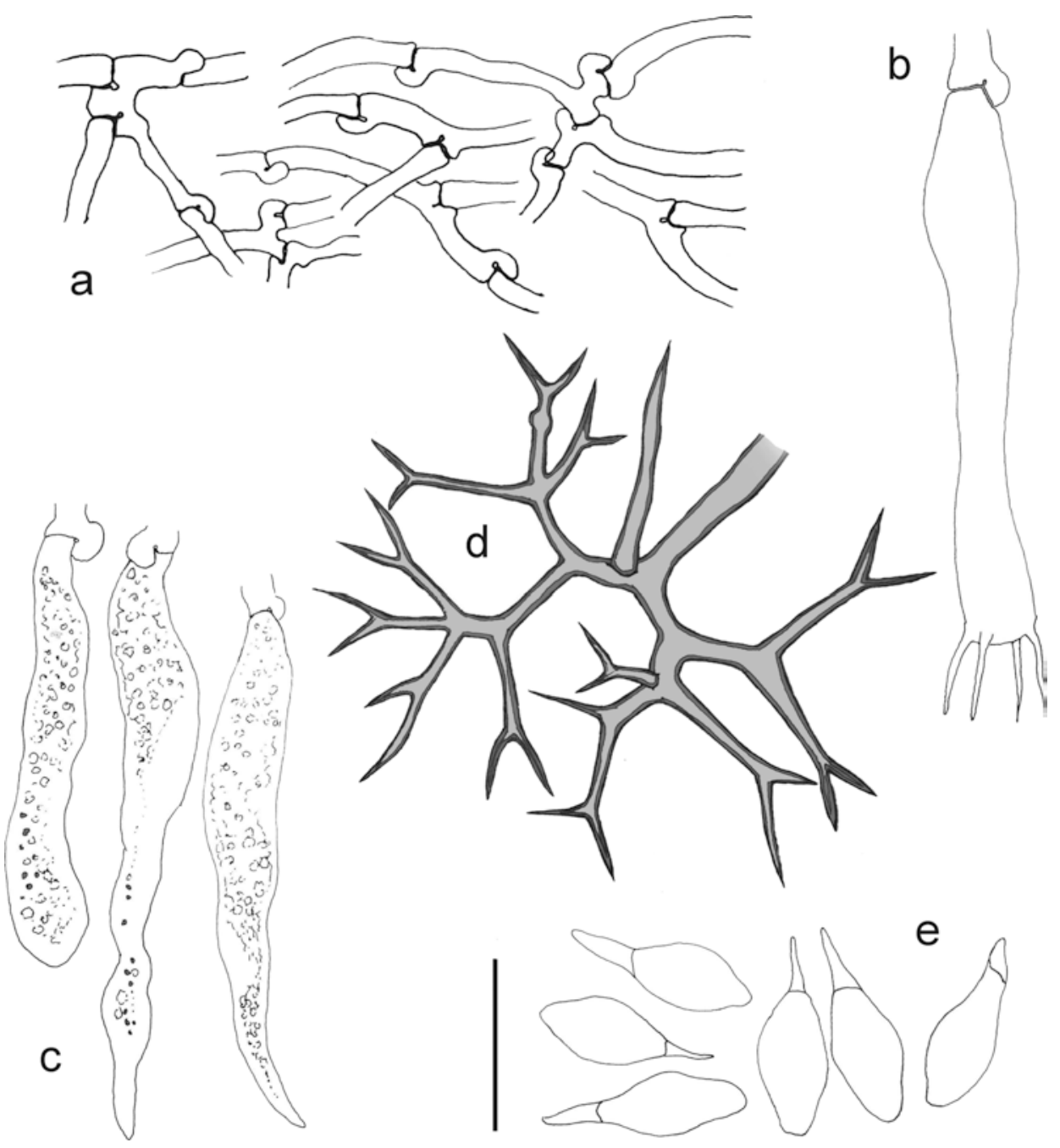

Fig. 6. Vararia investiens: a) subicular hyphae, b) basidium, c) gloeocystidia, d) dichohyphidium, e) spores KRAM F-48008. Scale bar $=10 \mu \mathrm{m}$.

(7.5-)8.5-11.2(-11.8) × (3.0-)3.2-4.0(-4.3) $\mu \mathrm{m}\left(\mathrm{L}^{\mathrm{m}}=10.66 \mu \mathrm{m} ; \mathrm{W}^{\mathrm{m}}=3.95 \mu \mathrm{m} ; \mathrm{Q}^{\mathrm{m}}=\right.$ 2.69; $\mathrm{Q}=2.25-3.47 ; \mathrm{n}=60)$, with amyloid suprahilar plage, non-cyanophilous.

Specimens eXamined. Poland. Pojezierza Południowobałtyckie lakelands, Pojezierze Kaszubskie lakeland, Staniszewskie Zdroje Reserve, ca. $1.5 \mathrm{~km} \mathrm{SW}$ of Mirachowo, on the slope of an unnamed stream ravine, on rotten wood of a fallen trunk of Populus tremula L., 4 July 2008, leg. D. Karasiński 1838 (KRAM F-48009); Ostrzycki Las Reserve, beech forest on the bank of the Jezioro Ostrzyckie lake, on rotten wood of a fallen branch of Fagus sylvatica and dead beech leaves in litter, 21 July 2009, leg. D. Karasiński 3497 (KRAM F-48008).

Comments. Main characters of Vararia investiens are the presence of clamp connections on generative hyphae and fusiform spores with a (pseudo)septum. Basidiospores are unique among European members of the genus: a (pseudo)septate 
spore tip is observed only in this species making its determination quite easy. Other species with fusiform spores with secondary (pseudo)septum are known from subtropical and tropical areas and, in general, their spores are longer than those of Vararia investiens.

Vararia investiens seems to be the most common, widely distributed, almost cosmopolitan species, so far known from Europe (e.g., Boidin, Michel 1998; Boidin, Gilles 1999), Asia (Parmasto 1970; Ying 1980; Teng 1996), North and Central America (Rogers, Jackson 1943; Gilbertson 1965; Welden 1965; Ginns, Lefebvre 1993), South America (Dennis 1970; Hjortstam, Ryvarden 2007) and Australia (Cunningham 1963) and New Zealand. Welden (1965) cited specimens of Vararia investiens from Puerto Rico, Jamaica, Canada and the USA. The material from Puerto Rico has spores measuring 18-21 × 3-4 $\mu \mathrm{m}$ which are longer than usually reported in Vararia investiens and the collection probably represents Vararia cremea Boidin, Lanq. \& Gilles.

In Europe Vararia investiens occurs in Denmark (Christiansen 1960), Estonia (Järva, Parmasto 1980), France (Boidin, Michel 1998; Boidin, Gilles 1999), Finland, Norway, Sweden (Hjortstam 1984; Hallenberg, Eriksson 1985), Germany (Krieglsteiner 1991), Italy (Onofri 2005), Spain (Tellería 1990) and Ukraine (Akulov et al. 2003).

From Poland the species was previously reported by Eichler (1900, 1904, as Corticium investiens (Schwein.) Bres.). The specimen reported in the 1900 paper was probably fertile and was identified by Bresadola. Subsequent collections, mentioned in the publication from 1904, were certainly sterile (Eichler (1904) wrote: "I did not see basidiospores")) and thus their determination should be regarded as uncertain.

Vararia ochroleuca (Bourdot \& Galzin) Donk

Figs 7-9

Ned. Kruid. Arch. 3: 79.

Asterostromella ochroleuca Bourdot \& Galzin, Bull. Soc. mycol. Fr. 27(2): 266 (1911).

Basidiocarps annual, resupinate, forming irregular, scattered patches when covering wood remnants in litter and widely effused, circular or elongate areas up to $20 \mathrm{~cm}$ long when growing on the underside of fallen branches and trunks, closely adnate, not separable, soft membranaceous to crustaceous, brittle with age and when dry. Hymenial surface smooth and indistinctly pruinose, cream-coloured to pallid ochraceous. Margin brighter than hymenial surface, whitish, thin or partially thinning out, farinose to delicately fibrillose, sometimes with a few narrow hyphal strands. Context on the transverse section white to cream-coloured, 120-270 $\mu \mathrm{m}$ thick. Hyphal system dimitic. Generative hyphae few, 2.0-3.0 $\mu \mathrm{m}$, without clamp connections, hyaline, rarely branched and sometimes with anastomoses. Dichohyphidia very abundant and of two kinds: 1) forming loose texture in the subicular and subhymenial layer, 0.5-1.8 $\mu \mathrm{m}$ thick, dichotomously branched, with long ultimate branches up to $45 \mu \mathrm{m}$ long; 2) dichohyphidia in hymenial layer with denser and shorter branches than subhymenial and subhymenial ones, more or less globose in outline, dichotomously branched, with short ultimate branches, 2.0-6.0 $\mu \mathrm{m}$ long, subulate at top, thick-walled, almost hyaline to straw-coloured or yellowish in $\mathrm{KOH}$ but strongly dextrinoid (dark red brown) in Melzer's reagent. Thick walls of dichohyphidia cyanophilous. The catahymenium consists of dichohyphidia as well as of gloeocystidia and basidia. Gloeocystidia 16-34 × 4.5-7.5 (10.0) $\mu \mathrm{m}$, with 

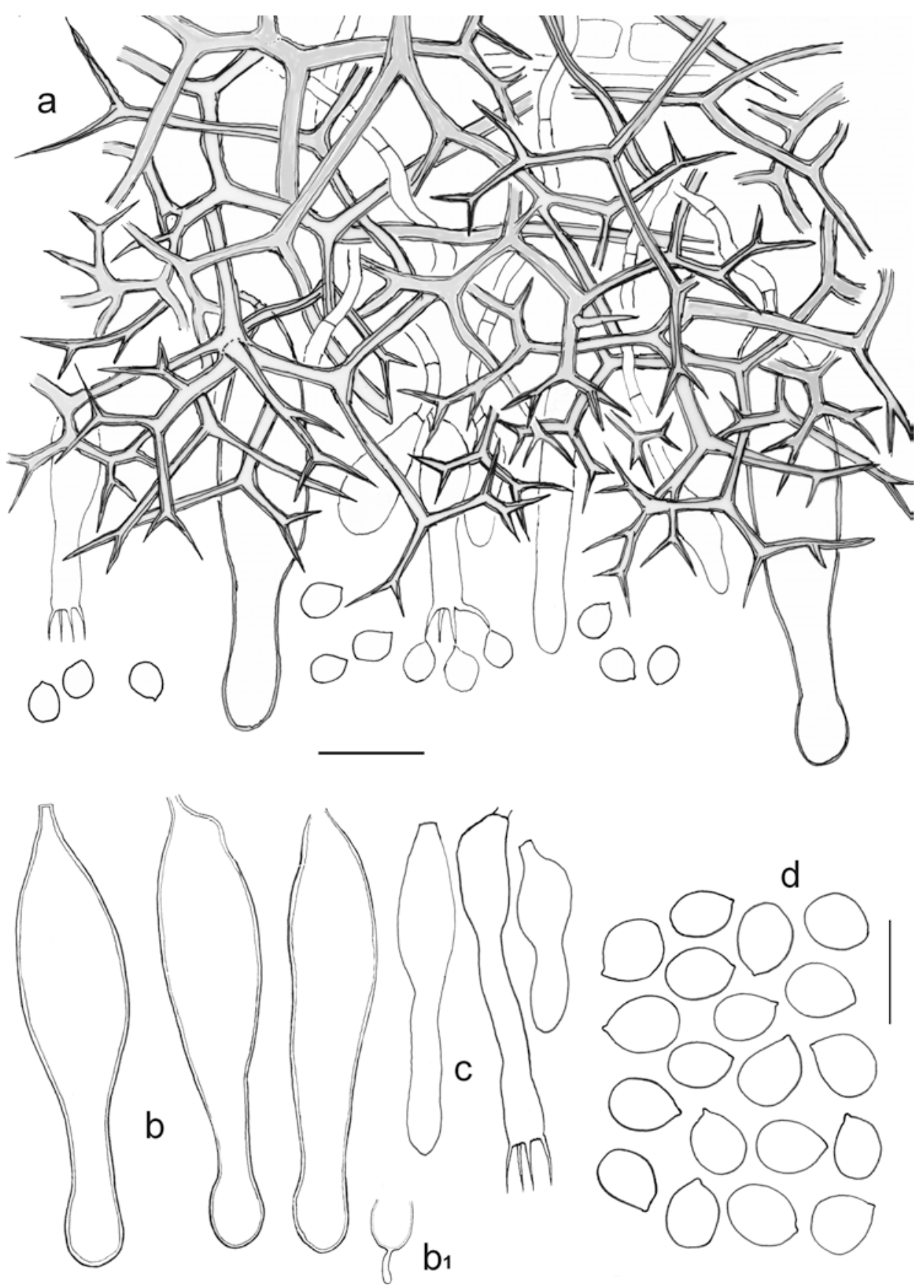

Fig. 7. Vararia ochroleuca: a) fragment of section through hymenial and subhymenial layer of basidocarp, b) gloeocystidia, b1) apex of gloeocystidium with schizopapillae, c) two basidioles and basidium, d) spores KRAM F-48007. Scale bars for a-c $=10 \mu \mathrm{m}$, for $\mathrm{d}=5 \mu \mathrm{m}$. 


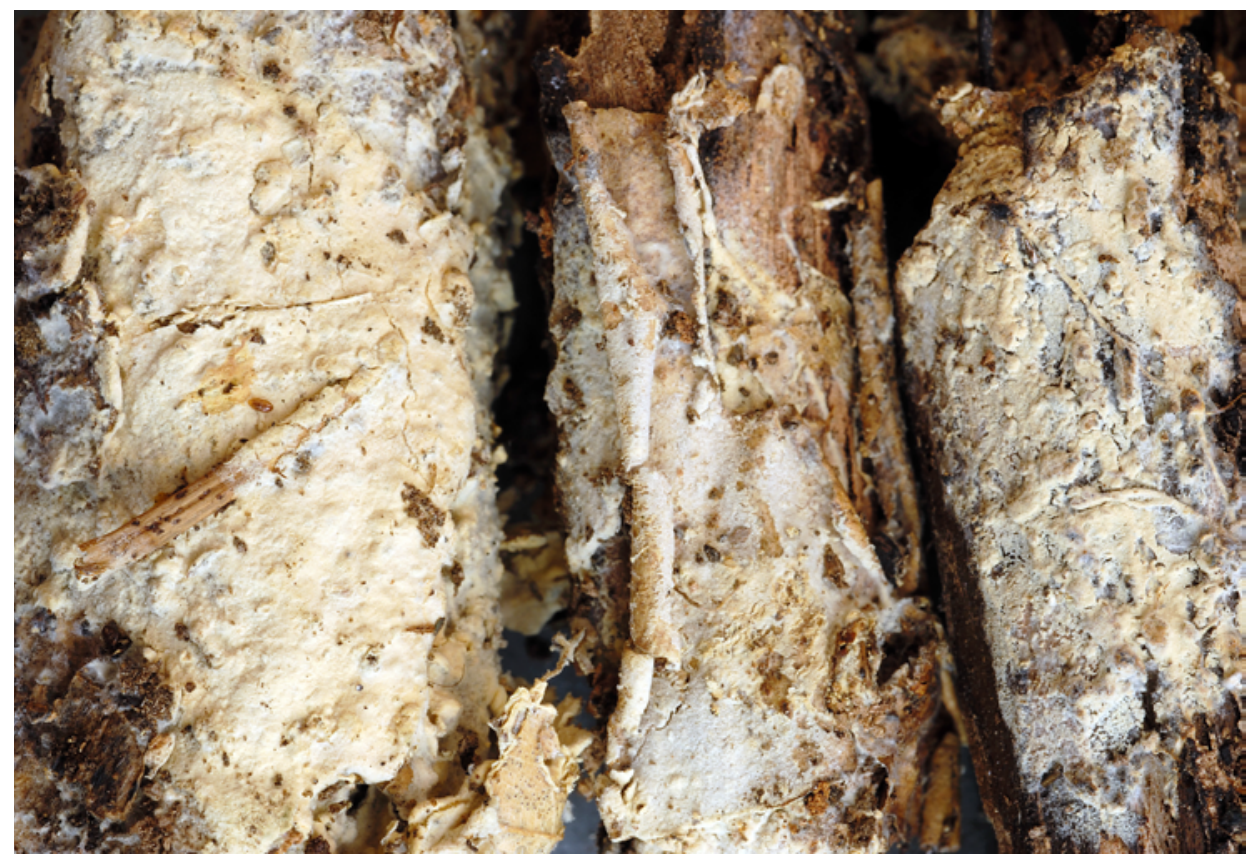

Fig. 8. Vararia ochroleuca on pieces of wood and plants remnants in forest litter KRAM F-48004 (Phot. D. Karasiński).

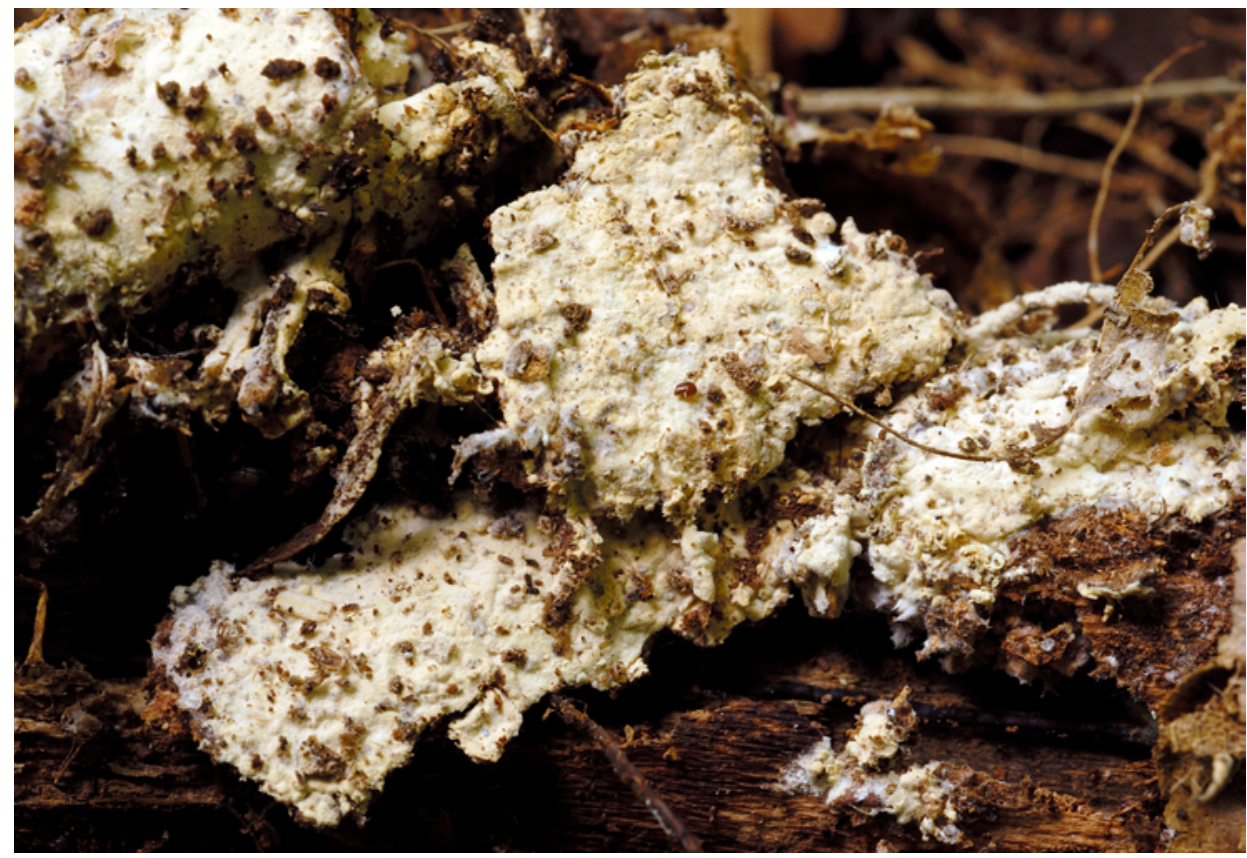

Fig. 9. Vararia ochroleuca on pieces of wood and plants remnants in forest litter KRAM F-48005 (Phot. D. Karasiński). 
walls slightly thickened with age, apex obtuse, but sometimes with a schizopapilla up to $8 \mu \mathrm{m}$ long. Basidia $25-38 \times 2.5-4.5 \mu \mathrm{m}$, utriform, with 4 sterigmata, without basal clamp, projecting over hymenial layer up to $20 \mu \mathrm{m}$. Spores (2.6-)2.8-3.8(-4.2) $\times(2.0-) 2.2-3.0(-3.2) \mu \mathrm{m}\left(\mathrm{L}^{\mathrm{m}}=3.42 \mu \mathrm{m} ; \mathrm{W}^{\mathrm{m}}=2.55 \mu \mathrm{m} ; \mathrm{Q}^{\mathrm{m}}=1.34 ; \mathrm{Q}=1.14-1.46\right.$; $\mathrm{n}=90$ ), mostly broadly ellipsoid to drop-shaped or sometimes somewhat subglobose, with non-prominent but distinctly visible apiculus, sometimes with one small oil-drop inside, thin-walled, smooth, hyaline, non-amyloid, non-dextrinoid, non-cyanophilous.

Specimens examined. Poland. Północne Podkarpacie region, Nizina Nadwiślańska lowland, Puszcza Niepołomicka forest, forest section 98, in a mixed anthropogenic forest with Fagus L., Pinus L. and Corylus L. growing on a pine-oak forest habitat, on small pieces of wood, fragments of deciduous and coniferous twigs, dead beech leaves, fallen pine needles and other plant remnants lying on the forest litter, 11 Apr. 2008, leg. D. Karasiński (KRAM F-48005); the same locality, habitat and host 18 May 2008, leg. D. Karasiński (KRAM F-48004); Wysoczyzny Podlasko-Białoruskie high plains, Równina Bielska plain, Białowieża Forest, Białowieża National Park, Hwoźna Protected Area, forest section 225A, 5246’38.3” N, 2351'52.1" E, humid oak-lime-hornbeam forest, on the bark of a fallen, strongly decayed trunk of Quercus robur L., 14 Sept. 2009, leg. D. Karasiński 4132 (KRAM F-48007).

Comments. The species is easily recognizable by its small, ellipsoid, non-amyloid spores, the absence of clamps on generative hyphae and sulphonegative, ventricose-rostrate and obtuse cystidia, very few with schizopapillae. In the field, Vararia ochroleuca may by confused with well developed specimens of Amphinema byssoides (Pers.) J. Erikss., which has the same ecological preferences and mostly covers wood remnants in forest litter. In addition, spores of both species are somewhat similar in shape and size. Basidiocarps of the latter are more delicate, softer, with a byssoid subiculum and distinctly fibrillose margin. Amphinema byssoides is monomitic and has hyphoid, finely encrusted leptocystidia, and lacks dextrinoid dichohyphidia.

Vararia ochroleuca is very rarely reported from Europe. It is overlooked in field studies because its inconspicuous basidiocarps, often hidden in forest litter. It is known from two localities in Sweden (Hallenberg, Eriksson 1985) and a single locality in Norway (Ryvarden et al. 2003). It is known from one record from Germany (Krieglsteiner 1991), a few collections from France (Boidin, Lanquetin 1975), the Netherlands (Donk 1930; Arnolds et al. 1995), Austria (Dämon 2001; Hallenberg, Michelitsch 1983), Great Britain (Legon et al. 2005), Estonia (Parmasto 1970; Järva, Parmasto 1980), Italy (Onofri 2005) and Spain (Tellería 1990). Outside Europe, it was recorded in Armenia and Asiatic Russia (Parmasto 1970). Vararia ochroleuca reported from India (Thind, Rattan 1973) represented Vararia vassilievae Parmasto (Rattan 1977). New Zealand's specimens published under the name Vararia ochroleuca (Cunnigham 1963) belongs to Vararia cunninghamii Boidin \& Lanq. (Boidin, Lanquetin 1975). It is currently known from New Zealand and southern Argentina (Greslebin, Rajchenberg 1997). Further small-spored species of Vararia, for example Vararia fibra Welden and Vararia alticola Corner \& Boidin occur in subtropical and tropical areas of the world (Welden 1965; Boidin, Lanquetin 1984). 


\section{KEY TO THE EUROPEAN SPECIES OF THE GENUS VARARIA}

This key is prepared based on literature data and specimens examined by the author. Four of the seven taxa included into the key were not recorded in Poland yet, but their occurrence in the country is possible.

As spore size and shape seem to be excellent features differentiating Vararia species known from Europe so far, the author used them as the main characters in the key. The presence or absence of clamp connections on generative hyphae, basidiocarps macromorphology and ecology are given as supplementary characters.

1. Basidiospores small, up to $4 \mu \mathrm{m}$ long, broadly ellipsoid to ovoid or subglobose, without amyloid reaction, clamps absent, on wood and plant remnants in litter V. ochroleuca $1 *$ Basidiospores shape and size not as above 2

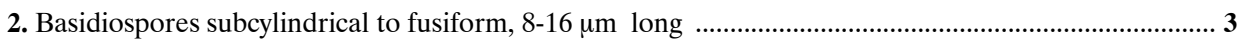

2*. Basidiospores ellipsoid-subcylindrical to suballantoid, up to $8 \mu \mathrm{m}$ long ...........................................6

3. Basidiospores usually with proximal part separated by secondary (pseudo)septum, generative hyphae with clamp connections, on hardwood and leaf litter

V. investiens

3*. Basidiospores without secondary (pseudo)septum, clamps absent

4. Basidiospores 12.0-16.0 × 3.7-4.5 $\mu \mathrm{m}$, subcylindrical, tapering towards apiculus, cystidia enclosed, obtuse, in context encrusted, on Thuja (Denmark, France) V. hauerslevii 4*. Basidiospores shorter, cystidia enclosed or partly projecting, obtuse or subulate, frequently with schizopapillae, not encrusted

5. Basidiocarps very thin, whitish, basidiospores 8.0-12.0 $\times 3.0-5.5 \mu \mathrm{m}$, cystidia 4-7 $\mu \mathrm{m}$ wide, on dead stems of herbaceous plants, rarely on fallen twigs (e.g., Salix) in wet localities V. gallica $5^{*}$. Basidiocarps powdery-membranaceous, cream-coloured, basidiospores 7.7-9.5 × 3.8-5.0 $\mu \mathrm{m}$, cystidia 6-9 $\mu \mathrm{m}$ wide, on wood in dry places (xerothermic habitats)

V. cremeoavellanea

6. Basidiospores ellipsoid-subcylindrical with one side straight, 5.5-7.5 $\times$ 2.5-3.0 $\mu \mathrm{m}$, with an amyloid suprahilar patch, generative hyphae without clamps, on wood of Picea abies, known from northern Europe (Sweden) V. racemosa ssp. lapponica

6*. Basidiospores suballantoid, 5.0-7.5 × 18-2.5 $\mu \mathrm{m}$, distinctly amyloid, clamps present, on Juniperus, known only from southern Europe (France, Italy) V. parmastoi

Acknowledgements. I would like to express my special thanks to Marcin Piątek (Kraków, Poland) for his help and suggestions on the manuscript and to the anonymous reviewer for very valuable comments on the paper. This work was partly supported by the Polish Ministry of Science and Higher Education (grant no. N N304 079535 for the years 2008-2011 and grant no. N305 017 31/0659 for the years 2006-2009).

\section{REFERENCES}

Akulov A. Y., Usichenko A. S., Leontyev D. V., Yurchenko E. O., Prydiuk M. P. 2003. Annotated checklist of aphyllophoroid fungi of Ukraine. Mycena 2 (2): 1-72.

Arnolds E. , Kuyper T. W., Noordeloos M. E. (eds). 1995. Overzicht van de Paddestoelen in Nederland. Nederlandse Mycologische Vereniging, Wijster.

Bernicchia A. 2001. Aphyllophoraceous wood-inhabiting Fungi of the Lanaittu Valley (Nuoro), Sardinia. Mycotaxon 77: 15-23.

Boidin J. 1967. Basidiomycètes Lachnocladiaceae résupinés de la République Centrafricaine. Cahiers de la Maboké 5 (1): 23-35.

Boidin J., Gilles G. 1999. Contribution à la connaissance du genre Vararia (Basidiomycotina). Bull. Soc. Mycol. France 115 (2): 115-139.

Boidin J., Gilles G., Lanquetin P. 1987. Basidiomycètes Aphyllophorales de l'île de la Réunion. IX - Les genres Dichostereum Pilát et Vararia Karsten. Bull. Soc. Mycol. France 103: 119-135. 
Boidin J., Lanquetin P. 1975. Vararia subgenus Vararia (Basidiomycetes, Lachnocladiaceae): étude spèciale des espèces d'Afrique intertropicale. Bull. Soc. Mycol. France 91 (4): 457-513.

Boidin J., Lanquetin P. 1977. Les genres Dichostereum et Vararia en Guadeoloupe. (Basidiomycetes, Lachnocladiaceae). Mycotaxon 6 (2): 277-336.

Boidin J., Lanquetin P. 1984. Compléments au genre Vararia P. Karst. (Basidiomycètes). Persoonia 12: $243-262$.

Boidin J., Lanquetin P., Terra P., Gomez C. E. 1976. Vararia subgenus Vararia (Basidiomycetes, Lachnocladiaceae), deuxième partie: caractères culturaux. Bull. Soc. Mycol. France 92 (2): 247-277.

Boidin J., Michel H. 1998. Les genres Vararia et Dichostereum en Europe (Basidiomycotina, Lachnocladiaceae). Bull. Soc. Mycol. France 114: 1-4.

Christiansen M. P. 1960. Danish Resupinate Fungi. Part 2. Homobasidiomycetes. Dansk Bot. Ark. 19 (2): 59-388.

Cunningham G. H. 1955. Thelephoraceae of New Zealand IV. The genus Vararia. Trans. Roy. Soc. New Zealand 82 (5): 973-985.

Cunningham G. H. 1963. The Thelephoraceae of Australia and New Zealand. Bull. New Zealand Dept. Sci. Industr. Res. 145: 1-359.

Dennis R. W. G. 1970. Fungus flora of Venezuela and adjacent countries. Kew Bull. Addit. Ser. 3: $1-531$.

Dämon W. 2001. Die corticioiden Basidienpilze des Bundeslandes Salzburg (Österreich). Floristik, Lebensräume und Substratökologie. Biblioth. Mycol. 189: 1-413.

Donk M. A. 1930. Nederlandse Basidiomyceten I. Ned. Kruidk. Arch. 3: 65-84.

Eichler B. 1900. Materiały do flory grzybów okolic Międzyrzeca. Pam. Fizjogr. 16: 157-206.

Eichler B. 1904. Drugi przyczynek do flory grzybów okolic Międzyrzeca. Pam. Fizjogr. 18: 1-31.

Gilbertson R. L. 1965. Some species of Vararia from temperate North America. Pap. Michigan Acad. Sci. 50: 161-184.

Gilbertson R. L., Hemmes D. E. 1997. Notes on fungi on Hawaiian tree ferns. Mycotaxon 62: 465-487.

Ginns J., Lefebvre M. N. L. 1993. Lignicolous Corticioid Fungi (Basidiomycota) of North America. Systematics, Distribution, and Ecology. Mycol. Mem. 19: 1-244. APS Press, Minnesota.

Greslebin A. G., Rajchenberg M. 1997. Corticioid Aphyllophorales (Basidiomycota) from the Patagonian Andes forests of Argentina. 1. Lachnocladiaceae on Nothofagus pumilo. Mycotaxon 65: 197-203.

Grosse-Brauckmann H., Kummer V. 2004. Fünf bemerkenwerte Funde corticioider Pilze aus Deutschland. Feddes Repert. 115 (1/2): 90-101.

Hallenberg N., Eriksson J. 1985. The Lachnocladiaceae and Coniophoraceae of North Europe. Fungiflora, Oslo.

Hallenberg N., Michelitsch S. 1983. Wood-Fungi from Styria, Austria. Windahlia 12/13: 39-56.

Hjortstam K. 1984. Corticiaceous fungi of northern Europe - check-list of the species in the Nordic countries. Windahlia 14: 1-29.

Hjortstam K., Ryvarden L. 2007. Checklist of corticioid fungi (Basidiomycotina) from the tropics, subtropics and the southern hemisphaere. Synop. Fungorum 22: 27-146.

Hjortstam K., Larsson K.- H., Ryvarden L. 1987. Corticiaceae of North Europe. 1. Introduction and keys. Fungiflora, Oslo.

Järva L., Parmasto E. 1980. List of Estonian fungi. Scripta Mycol. 7: 1-331.

Karsten P. A. 1889. Kritisk Öfversigt af Finlands Basidsvampar (Basidiomycetes; Gastero- \& Hymenomycetes). Bidrag till Kännedom af Finlands Natur och Folk 48: 1-470.

Karsten P. A. 1898. Kritisk Öfversigt af Finlands Basidsvampar. Tillägg 3: 1-36.

Krieglsteiner G. J. 1991. Verbreitungsatlas der Großpilze Deutschlands (West). Band 1: Ständerpilze. Teil A: Nichtblätterpilze. Verlag Eugen Ulmer, Stuttgart.

Larsson K.-H. 2007. Re-thinking the classification of corticioid fungi. Mycol. Res. 111: 1040-1063.

Legon N. W., Henrici A., Roberts P. J., Spooner B. M., Watling R. 2005. Checklist of the British and Irish Basidiomycota. Royal Botanic Gardens, Kew.

Matuszkiewicz W. 2007. Przewodnik do oznaczania zbiorowisk roślinnych Polski. PWN, Warszawa.

Mazurkiewicz-Zapałowicz K., Wróbel M., Silicki A., Wolska M. 2006. Studies on phytopathogenic and saprotrophic fungi in rush associations of Lake Glinno (NW Poland). Acta Mycol. 41 (1): 125-138.

Miller S. L., Larsson E., Larsson K.-H., Verbeken A., Nuytinck J. 2006. Perspectives in the new Russulales. Mycologia 98 (6): 960-970. 
Onofri S. (ed.) 2005. Checklist of Italian Fungi: Basidiomycota. Carlo Delfino Editore for Organization for the Phyto-Taxonomic Investigation of the Mediterranean Area, Sassari.

Parmasto E. 1965. Corticiaceae U.R.S.S. I. Descriptiones taxorum novarum. Combinationes novae. Eesti NSV Teaduste Akadeemia Toimetised 14 (2): 220-233.

Parmasto E. 1970. The Lachnocladiaceae of the Soviet Union with a key to boreal species. Scripta Mycol. 2: $1-168+105$ figs.

Parmasto E., Parmasto I. 2005. Fungi of Ruhnu Island (Estonia). Estonia Maritima 7: 5-84.

Pouzar Z. 1982. Taxonomic studies in resupinate fungi I. Česká Mykol. 36 (3): 141-145.

Rattan S. S. 1977. The Resupinate Aphyllophorales of the North Western Himalayas. Biblioth. Mycol. 60: $1-427$.

Rogers D. P., Jackson H. S. 1943. Notes on the synonymy of some North American Thelephoraceae and other resupinates. Farlowia 1 (2): 263-328.

Ryvarden L., Stockland J., Larsson K.-H. 2003. A critical checklist of corticoid and poroid fungi of Norway. Synop. Fungorum 17: 1-79.

Tellería M. T. 1990. Annotated list of the Corticiaceae, sensu lato (Aphyllophorales, Basidiomycotina), for Peninsular Spain and Balearic Islands. Biblioth. Mycol. 135: 1-152.

Teng S. C. 1996. Fungi of China. Mycotaxon, Ltd, Ithaca.

Thind K. S., Rattan S. S. 1973. The Thelephoraceae of India - VII. Indian Phytopathol. 26: 528-536.

Welden A. L. 1965. West Indian species of Vararia with notes on extralimital species. Mycologia 57: 502520.

Ying J. Z. 1980. A preliminary study on the resupinate Aphyllophorales from China. Acta Bot. Yunnan. 2: $241-274$.

\section{Polskie Russulales o rozpostartych owocnikach: rodzaj Vararia}

\section{Streszczenie}

W pracy przedstawiono 3 rzadko notowane gatunki grzybów kortycjoidalnych z rodzaju Vararia (Basidomycota, Agaricomycetes, Russulales). Materiały zebrano w Kaszubskim Parku Krajobrazowym, Białowieskim Parku Narodowym i Puszczy Niepołomickiej. Vararia gallica i Vararia ochroleuca są nowe dla mikobioty Polski. Vararia investiens była znana wcześniej z okolic Międzyrzeca Podlaskiego gdzie gatunek ten ostatni raz zbierano ponad 100 lat temu. Zamieszczono szczegółowe opisy polskich okazów i oryginalne ilustracje cech makro- i mikromorfologicznych omawianych grzybów. Praca zawiera również podsumowanie wiedzy o ich rozmieszczeniu i ekologii, a także krótkie dyskusje taksonomiczne. Zaproponowano klucz do rodzaju Vararia uwzględniający taksony stwierdzone dotychczas w Europie. 